33-34 | 2003

Sortir de la nuit

Jean-Luc Lambert

\title{
Chapitre I. La fête annuelle
}

Chapter I. The annual festival

Jean-Luc Lambert

\section{(2) OpenEdition}

Journals

Édition électronique

URL : https://journals.openedition.org/emscat/1360

DOI : 10.4000/emscat.1360

ISSN : 2101-0013

Éditeur

Centre d'Etudes Mongoles \& Sibériennes / École Pratique des Hautes Études

Édition imprimée

Date de publication : 2 décembre 2003

Pagination : 107-160

ISSN : 0766-5075

Référence électronique

Jean-Luc Lambert, «Chapitre I. La fête annuelle », Études mongoles et sibériennes, centrasiatiques et tibétaines [En ligne], 33-34 | 2003, mis en ligne le 17 mars 2009, consulté le 13 juillet 2021. URL : http:// journals.openedition.org/emscat/1360; DOI : https://doi.org/10.4000/emscat.1360

Ce document a été généré automatiquement le 13 juillet 2021

(C) Tous droits réservés 


\title{
Chapitre I. La fête annuelle
}

\author{
Chapter I. The annual festival
}

\author{
Jean-Luc Lambert
}

\section{RÉSUMÉS}

C'est au sortir de la nuit polaire, fin janvier, que les trois groupes nganassanes (Nganassanes avames, Nganassanes de Taïmyr, Nganassanes vadéiefs) organisent leur fête annuelle, rite de grande ampleur durant jusqu'à neuf jours d'affilée. Au cours de celui-ci, les jeunes célibataires dansent et luttent sur un lac gelé près duquel a été dressée une hutte cérémonielle où officie le chamane en charge du rituel. Le premier jour, il se rend à la hutte " pure » - construction où ne peuvent pénétrer les âmes des morts -, un bandeau sur les yeux et une canne en fer à la main. Or, ces objets sont précisément ceux qu'utilise le chamane samoyède pour son voyage chez les défunts. De plus, la direction du déplacement du chamane en ce premier jour de fête suggère qu'il sort symboliquement du monde des morts. Les jours suivants, il continuera son périple vers le sud et devra réussir diverses épreuves imposées par les esprits, comme de retrouver des lanières rituelles dissimulées.

The three Nganasan groups (Avam Nganasans, Taimyr Nganasans, Vadeev Nganasans) organize their annual festival towards the end of the polar night at the end of January. This is a large-scale ritual which may last up to nine consecutive days. During the festival young bachelors dance and wrestle on a frozen lake near which the shaman in charge of the ritual officiates in a purposebuilt ceremonial hut. On the first day he goes to the "pure" hut (into which the souls of the dead can not enter) holding an iron cane and with a band over his eyes. These are exactly the artefacts which a Samoyed shaman uses for his journey to the world of the dead. Moreover the direction in which the Nganasan shaman moves on this occasion suggests that he is symbolically leaving the world of the dead. On the following days he continues his journey to the south and will have to undergo various trials prescribed by the spirits, for example finding hidden ritual thongs. 
INDEX

nomsmotscles Enets, Nenets, Nganasan, Samoyède

Thèmes : chamanisme, fêtes, littérature, mythologie, nomadisme, organisation sociale, parenté, religion, représentations

Index géographique : Arctique, Russie, Sibérie occidentale, Sibérie septentrionale, Taïmyr, Toundra

Mots-clés : alliance, chamane, mythe, rituel

Keywords : marriage, myth, ritual, shaman 